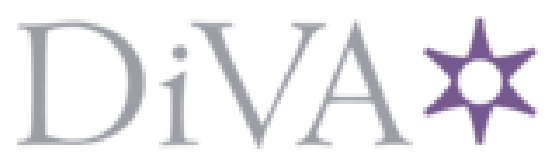

http://www.diva-portal.org

\title{
Postprint
}

This is the accepted version of a paper published in Journal of Organic Chemistry. This paper has been peer-reviewed but does not include the final publisher proof-corrections or journal pagination.

Citation for the original published paper (version of record):

Gustafson, K P., Lihammar, R., Verho, O., Engström, K., Bäckvall, J-E. (2014)

Chemoenzymatic Dynamic Kinetic Resolution of Primary Amines Using a Recyclable Palladium Nanoparticle Catalyst Together with Lipases.

Journal of Organic Chemistry, 79(9): 3747-3751

http://dx.doi.org/10.1021/jo500508p

Access to the published version may require subscription.

N.B. When citing this work, cite the original published paper.

Permanent link to this version:

http://urn.kb.se/resolve?urn=urn:nbn:se:su:diva- 104395 


\section{Chemoenzymatic Dynamic Kinetic Resolution of Primary Amines Using a Recyclable Palladium Nanoparticle Catalyst Together with Lipases}

Karl P. J. Gustafson, Richard Lihammar, Oscar Verho, Karin Engström, and Jan-E. Bäckvall* Department of Organic Chemistry, Arrhenius Laboratory, Stockholm University, SE-106 91 Stockholm, Sweden

\section{jeb@organ.su.se}

Abstract. A catalyst consisting of palladium nanoparticles supported on amino-functionalized siliceous mesocellular foam (Pd-AmP-MCF) was used in chemoenzymatic dynamic kinetic resolution (DKR) to convert primary amines to amides in high yields and excellent $e e$ 's. The efficiency of the nanocatalyst at temperatures below $70{ }^{\circ} \mathrm{C}$ enables reaction conditions that are more suitable for enzymes. In the present study this is exemplified by subjecting 1phenylethylamine (1a) and analogous benzylic amines to DKR reactions using two commercially available lipases, Novozyme-435 (Candida antartica Lipase B) and Amano Lipase PS-C1 (lipase from Burkholderia cepacia) as biocatalysts. The latter enzyme has not previously been used in the DKR of amines, due to its low stability at temperatures over 60 ${ }^{\circ} \mathrm{C}$. The viability of the heterogeneous Pd-AmP-MCF was further demonstrated in a recycling study, which shows that the catalyst can be reused up to five times.

\section{Introduction}

During the past three decades, a significant part of synthetic organic chemistry has been dedicated towards the development of new and efficient methods for the preparation of enantiomerically enriched compounds. Many of these methods utilize chiral catalysts in the enatiodetermining step, thereby increasing the reaction efficiency and minimizing the amount of reagents required. ${ }^{1}$ A common way to prepare enantiomerically enriched molecules is to 
utilize the chiral environment of an enzyme in a kinetic resolution. ${ }^{2}$ In this process the enzyme catalyzes the chemical transformation of one enantiomer faster than that of its mirror image, resulting in a separation of the two enantiomers. The drawback of this process is that the yield of the enantiomerically enriched product can never exceed 50\%. An excellent way to circumvent this limitation is to carry out the kinetic resolution in parallel with an in situ racemization, thus creating a dynamic kinetic resolution (DKR), theoretically increasing the yield up to $100 \%$ of a single product enantiomer. ${ }^{3}$ The enzymes employed are usually immobilized onto a solid support to increase stability, whereas the racemization is often catalyzed by homogenous transition metal complexes. An attractive way to make the process more environmentally friendly and to enhance the recyclability is to attach the racemization catalysts to a heterogeneous support. Recently, heterogeneous metal nanoparticles have attracted considerable attention as they have been found to be highly efficient and selective catalysts for a wide range of organic transformations. ${ }^{4}$ It has been demonstrated that the selectivity and reactivity exhibited by the nanoparticles are dependent on the size and shape of the particles as well as the type of support to which the particles are attached. $4^{\mathrm{c}, \mathrm{d}}$ Many different supports have been used for catalytic applications such as metal oxides, ${ }^{5}$ metal organic frameworks (MOFs), ${ }^{6}$ carbon-based polymers ${ }^{7}$ and silicas. ${ }^{8}$ Within the last group mentioned, siliceous mesocelluar foam (MCF) has shown to be an excellent material for supporting metal nanoparticles, enzymes and various heterogonous complexes. ${ }^{9}$ The MCF has a three dimensional morphology with large pores and a high surface area. In addition, the material possesses a high surface concentration of silanol groups that enables grafting with a variety of functional groups in a straight-forward fashion. ${ }^{9}$

Recently, we have reported on an amino-functionalized MCF as a support for $\mathrm{Pd}$ nanoparticles and demonstrated several application of this nanocatalyst. ${ }^{10}$ For instance the Pd nanocatalyst was found to efficiently racemize primary amines at low temperatures, ${ }^{10 a}$ which 
generally has been an issue with previously reported transition metal-based protocols. Elevated temperature has been required to overcome the strong coordination between the metal catalyst and the amine substrate, which has severely decreased the rate of amine racemization. ${ }^{11}$ The necessity of increased temperatures in the DKR has so far limited the use of enzymes to essentially thermostable lipases such as Candida antarctica Lipase A and B (CALA and CALB respectively), where the latter being by far the most utilized owing to its high selectivity and activity. ${ }^{12}$ Moreover, it has been shown that the formation of byproducts increases at elevated temperatures, mainly as a consequence of undesired side reactions with the sensitive imine intermediate that are formed during the course of the racemization ( $c f$. Scheme 1). The imine intermediate can easily undergo hydrolysis to the corresponding ketone or self-condense with another molecule of amine to form the secondary amine. The secondary amine can then further react under reductive conditions, yielding the starting material and ethylbenzene. $^{11}$

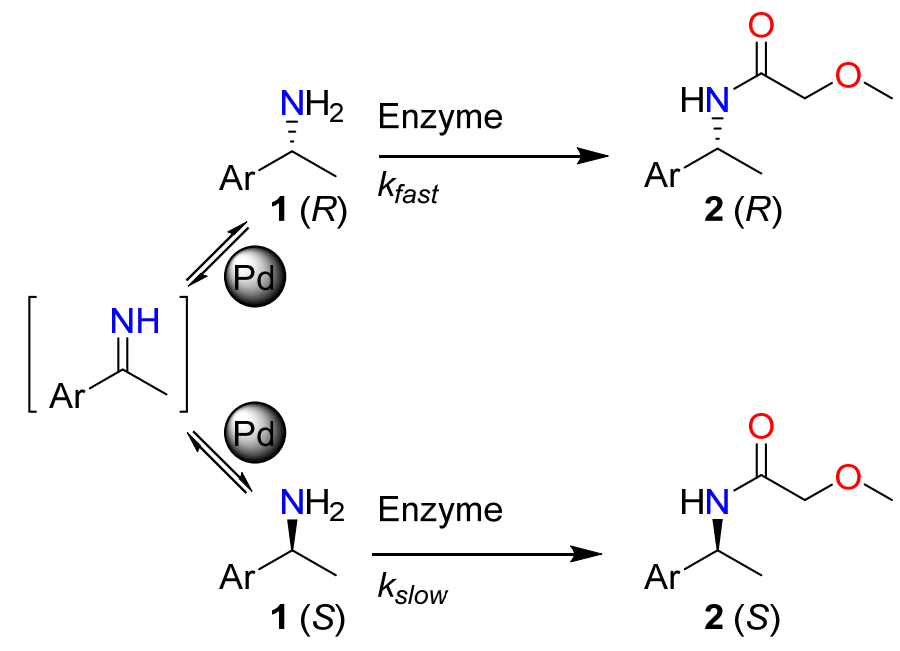

Scheme 1: Illustration of an $(R)$-selective dynamic kinetic resolution of primary benzyl amines using palladium nanoparticles as racemization catalyst and a methoxyacetate ester as acyl donor.

To date only a few enzyme-compatible metal complexes exist that are capable of racemizing amines. ${ }^{12 a, 13}$ Among these complexes a homogenous dimeric ruthenium hydride complex is 
still to date the most versatile catalyst for the DKR of amines. ${ }^{12 a, 13 a}$ However, the protocol required elevated temperatures $\left(90{ }^{\circ} \mathrm{C}\right.$ and higher), diluted reaction conditions and suffered from long reaction times ( 3 days). ${ }^{12 a, 13 a}$ Kim and Park developed a nanostructured palladium catalyst supported on $\mathrm{Al}(\mathrm{O}) \mathrm{OH}$ that was optimized to perform the racemization at lower temperatures than the ruthenium catalyst; however, dilute reactions conditions and long reaction times were still required. ${ }^{13 b, c}$ By applying our recently developed Pd-AmP-MCF as racemization catalyst in a chemoenzymatic DKR we envisioned to address these drawbacks and allow for the use of less thermostable enzymes.

\section{Results and discussion}

To find the optimal reaction condition 1-phenylethylamine (1a) was selected as model substrate, and subjected to a DKR at $70{ }^{\circ} \mathrm{C}$ using CALB as resolving agent, 2 equiv. of ethyl methoxyacetate (3) as acyl donor, ${ }^{14} 2.5 \mathrm{~mol} \%$ of Pd-AmP-MCF as racemization catalyst and 1 equiv. of $\mathrm{Na}_{2} \mathrm{CO}_{3}$ in dry toluene under $\mathrm{H}_{2}$ atmosphere $(1 \mathrm{~atm})$. The DKR was found to proceed smoothly and resulted in $63 \%$ conversion after $24 \mathrm{~h}$ (Table 1, entry 1). By concentrating the reaction from $0.15 \mathrm{M}$ to $0.4 \mathrm{M}$, the efficiency of the DKR was significantly increased (entry 2), reaching completion already after $16 \mathrm{~h}$. To our delight, we were able to isolate amide 2a in quantitative yield with no sign of byproduct formation. The most significant improvement was observed upon addition of molecular sieves (4 $\AA$ ) to the reaction as this reduced the reaction time to 5-6 h (entry 3). Moreover, it proved to be possible to reduce the loading of the $\mathrm{Pd}$ nanocatalyst to $1.25 \mathrm{~mol} \%$, and still maintain high yields and excellent enantioselectivity of the desired amide 2a (entry 4). To the best of our knowledge this is the lowest catalyst loading (Pd and CALB) ever used for these short reaction times in the DKR of primary amines. 
Table 1: Optimization of the DKR of $1 \mathrm{a}$ at $70{ }^{\circ} \mathrm{C}^{\mathrm{a}}$

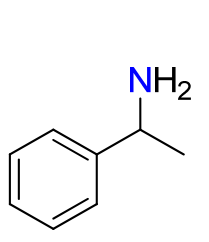

$1 \mathrm{a}$

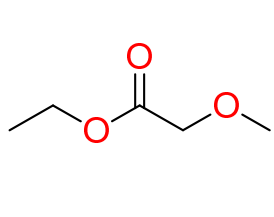

3
Pd-AmP-MCF

CALB

Additive

Toluene, $\mathrm{H}_{2}$ (1 atm)

$70^{\circ} \mathrm{C}$

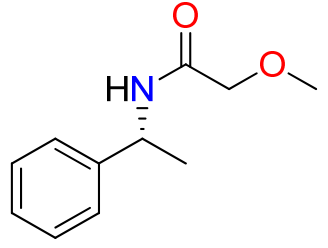

$2 a$

\begin{tabular}{|l|l|l|c|c|c|c|}
\hline Entry & Pd-loading & Additive & Time $(\mathrm{h})$ & $\begin{array}{l}\text { Toluene } \\
(\mathrm{mL})\end{array}$ & ${\text { Conv. }(\%)^{\mathrm{b}}}^{\mathrm{b}}$ & ${\text { ee }(\%)^{\mathrm{c}}}^{\mathrm{c}}$ \\
\hline 1 & $2.5 \mathrm{~mol} \%$ & $\mathrm{Na}_{2} \mathrm{CO}_{3}(1$ equiv. $)$ & 24 & 4 & 63 & 99 \\
\hline 2 & $2.5 \mathrm{~mol} \%$ & $\mathrm{Na}_{2} \mathrm{CO}_{3}(1$ equiv. $)$ & 16 & 1.5 & 99 & 99 \\
\hline 3 & $2.5 \mathrm{~mol} \%$ & Mol. sieves $4 \AA$ & 6 & 1.5 & 99 & 99 \\
\hline 4 & $1.25 \mathrm{~mol} \%$ & Mol. sieves $4 \AA$ & 6 & 1.5 & 99 & 99 \\
\hline
\end{tabular}

a) All reactions were carried out in dry toluene $(1.5 \mathrm{~mL})$ under $1 \mathrm{~atm}$ of hydrogen gas using 1a $(0.6 \mathrm{mmol}), 3$ (1.2 mmol), Novozyme-435 (CALB, $15 \mathrm{mg})$, molecular sieves $(300 \mathrm{mg})$ or $\mathrm{Na}_{2} \mathrm{CO}_{3}(60 \mathrm{mg})$ and pentadecane as internal standard. b) Determined using chiral GC and pentadecane as internal standard. c) Determined using by GC (error $99 \pm 0.02$ )

Inspired by the efficient $\mathrm{DKR}$ at $70{ }^{\circ} \mathrm{C}$ we set out to optimize the protocol to also provide a functioning DKR reaction at $50{ }^{\circ} \mathrm{C}$. To maintain an efficient racemization even at this temperature $5 \mathrm{~mol} \%$ of $\mathrm{Pd}-\mathrm{MCF}$ was used. Both molecular sieves and $\mathrm{Na}_{2} \mathrm{CO}_{3}$ could be used as additives to give full conversions and excellent $e e$ 's; however, the latter showed slightly higher ee (Table 2, entries 1-2). Control experiment on 1a, where CALB was omitted, showed that molecular sieves caused a slow background amidation which could explain the lower ee obtained when the reaction time is prolonged. ${ }^{15}$ When reducing the amount of Pd nanocatalyst from $5 \mathrm{~mol} \%$ to $2.5 \mathrm{~mol} \%$ the reaction still gave 2a in $99 \%$ ee but required a longer reaction time $(36 \mathrm{~h})$ to reach completion (entry 3 ). The possibility to run the reactions at lower temperatures also enables a broader range of enzymes to be used in the DKR, which potentially could widen the substrate scope. This novel feature was demonstrated by employing Amano Lipase PS-C1 (lipase from Burkholdera cepacia immobilized on ceramic beads) in a DKR with 5 mol\% of Pd-AmP-MCF which afforded 2a in a good isolated yield and excellent ee (entry 4). ${ }^{16}$ This enzyme has previously been used in the kinetic resolution of 
1a, but to the best of our knowledge this is the first example of a DKR of amines using this biocatalyst. $^{17}$

Table 2: Optimization of the reaction at $50{ }^{\circ} \mathrm{C}$ and evaluation of two different lipases.<smiles>CC(N)c1ccccc1</smiles>

$1 \mathrm{a}$<smiles>CCOC(=O)COC</smiles>

3

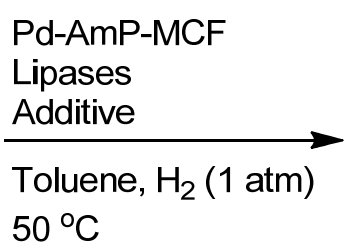

$50^{\circ} \mathrm{C}$

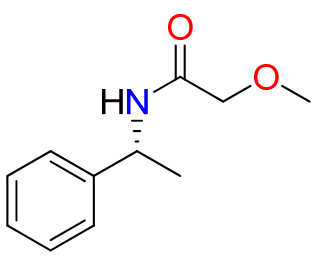

$2 a$

\begin{tabular}{|l|l|l|c|c|c|c|}
\hline Entry & Pd-loading & Additive & Time (h) & Lipase & Conv. $(\%)^{\text {b }}$ & ee (\%) \\
\hline 1 & $5 \mathrm{~mol} \%$ & Mol. sieves $4 \AA$ & 24 & CALB & 99 & 98 \\
\hline 2 & $5 \mathrm{~mol} \%$ & $\mathrm{Na}_{2} \mathrm{CO}_{3}(1$ equiv. $)$ & 24 & CALB & 99 & 99 \\
\hline 3 & $2.5 \mathrm{~mol} \%$ & $\mathrm{Na}_{2} \mathrm{CO}_{3}(1$ equiv. $)$ & 36 & CALB & 99 & 99 \\
\hline $4^{\mathrm{d}}$ & $5 \mathrm{~mol} \%$ & $\mathrm{Na}_{2} \mathrm{CO}_{3}(1$ equiv. $)$ & 36 & Lipase PS & $82^{\mathrm{e}}$ & 99 \\
\hline
\end{tabular}

a) All reactions were carried out in dry toluene $(1.5 \mathrm{~mL})$ under 1 atm hydrogen gas using 1 a $(0.6 \mathrm{mmol}), 3$ (1.2 mmol), Novozyme-435 (CALB, $15 \mathrm{mg})$, molecular sieves $\left(300 \mathrm{mg}\right.$ ) or $\mathrm{Na}_{2} \mathrm{CO}_{3}(60 \mathrm{mg})$ and pentadecane as internal standard. b) Determined using chiral GC and pentadecane as internal standard. c) Determined by chiral GC $(98 \pm 0.02 ; 99 \pm 0.02)$ d) Reaction was carried out in dry toluene $(2 \mathrm{~mL})$ under 1 atm hydrogen gas using 1 a (0.6 mmol), 3 (1.2 mmol), Amano Lipase PS-C1 (200 mg) and dry $\mathrm{Na}_{2} \mathrm{CO}_{3}(60 \mathrm{mg})$. e) Isolated yield.

After establishing the optimized protocols for the DKR at $70{ }^{\circ} \mathrm{C}$ and $50{ }^{\circ} \mathrm{C}$, a set of substrates were studied in the reaction at $70{ }^{\circ} \mathrm{C}$ (Table 3). Four benzylic amines substituted with aliphatic substituents were chosen and were all converted into their corresponding enantiomerically enriched amides in high yields as well as excellent $e e^{\text {'s }}$ (2a, $\mathbf{2} \mathbf{b}, \mathbf{2} \mathbf{c}$ and $\mathbf{2 d}$ ). Bicyclic tetrahydronaphthyl compound 2e was also isolated in close to quantitative yield and perfect ee. For the heteroatom substituted benzyl amines 1f and $\mathbf{1 g}$ the molecular sieves needed to be exchanged for $\mathrm{Na}_{2} \mathrm{CO}_{3}$ and the catalyst loading was increased to $2.5 \mathrm{~mol} \%$ in order to avoid unwanted background amidation. Substrate 1f bearing an electron-donating substituent worked excellently, while $\mathbf{2 g}$, with an electron-withdrawing substituent, was obtained in slightly lower yield (89\%) but still high ee. The amount of Pd nanocatalyst used in these DKR reactions with reasonably short reaction times are lower than previously reported 
for these compounds and the reactions are made at a substrate concentrations of $0.4 \mathrm{M}$, which is significantly higher than those previously reported. ${ }^{11}$

Table 3: Substrate scope of the DKR at $70{ }^{\circ} \mathrm{C}$ using Pd-AmP-MCF as racemization catalyst.<smiles>[R]C(N)[AlH2]</smiles>

Pd-AmP-MCF (1.25-2.5 mol\%) CALB $(25 \mathrm{mg} / \mathrm{mmol})$

Toluene, $\mathrm{H}_{2}$ (1 atm) 2a-g

Mol. sieves $4 \AA$ or $\mathrm{Na}_{2} \mathrm{CO}_{3}$

$70{ }^{\circ} \mathrm{C}, 6-16 \mathrm{~h}$<smiles>COCC(=O)NC(C)c1ccccc1</smiles>

$2 a^{a}$

Yield: $99 \%$

ee: $99 \%$<smiles>COCC(=O)N[C@@H](C)c1ccc(C)cc1</smiles>

$2 \mathbf{d}^{\mathrm{a}, \mathrm{c}}$

Yield: $91 \%$

ee: $98 \%$<smiles>COCC(=O)N[C@@H](C)c1ccc(C(F)(F)F)cc1</smiles>

$2 g^{b}$

Yield: $89 \%$

ee: $97 \%$<smiles>COCC(=O)NC(C)c1cccc(C)c1</smiles>

$2 b^{a}$

Yield: $87 \%$

ee: $99 \%$<smiles>COCC(=O)N[C@H]1CCCc2ccccc21</smiles>

Yield: 95\%

ee: $99 \%$<smiles>CCC(NC(=O)COC)c1ccccc1</smiles>

$2 c^{a}$

Yield: 97\%

ee: $97 \%$<smiles>COCC(=O)N[C@@H](C)c1ccc(OC)cc1</smiles>

Yield: 96\%

ee: $99 \%$

a) Method A: Reaction was performed in dry toluene $(1.5 \mathrm{~mL})$ under 1 atm hydrogen gas using Pd-AmP-MCF (10 mg, $1.25 \mathrm{~mol} \%)$, corresponding amine (0.6 mmol), ethyl methoxyacetate $(1.2 \mathrm{mmol})$, Novozyme-435 (15 $\mathrm{mg}$ ) and molecular sieves (300 mg). b) Method B: Reaction was performed in dry toluene (1.5 mL) under $1 \mathrm{~atm}$ hydrogen gas using Pd-AmP-MCF (20 mg, $2.5 \mathrm{~mol} \%)$, corresponding amine (0.6 mmol), ethyl methoxyacetate (1.2 mmol), Novozyme-435 (15 mg) and dry $\mathrm{Na}_{2} \mathrm{CO}_{3}(60 \mathrm{mg})$. c) $2.0 \mathrm{~mol} \%$ racemization catalyst was used. 
Finally, the stability of the heterogonous Pd nanocatalyst was assessed in a recycling study where the DKR of 1a was carried out under the optimized conditions with $2.5 \mathrm{~mol} \%$ of $\mathrm{Pd}$ nanocatalyst over five cycles. The DKR was allowed to continue for $15 \mathrm{~h}$ after which the PdAmP-MCF was separated, washed and used in a new DKR reaction. In this recycling, the catalytic system showed excellent conversion and ee until the fifth run where the conversion dropped to $90 \%$ and the $e e$ was $98 \%$ (see Table 4$).{ }^{18}$

Table 4: Recycling of the catalyst in the $\mathrm{DKR}^{\mathrm{a}}$<smiles>CC(N)c1ccccc1</smiles>

1a<smiles>CCOC(=O)COC</smiles>

3
Pd-AmP-MCF (2.5 mol\%)

CALB $(25 \mathrm{~g} / \mathrm{mol})$

Mol. sieves $4 \AA$

Toluene, $\mathrm{H}_{2}(1 \mathrm{~atm})$ $70^{\circ} \mathrm{C}$

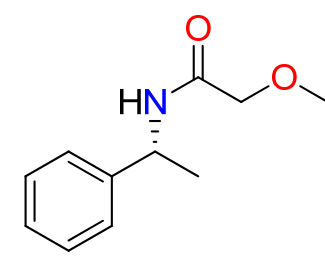

2a

\begin{tabular}{|c|c|c|}
\hline Cycle & Conv. $(\%)^{\mathrm{b}}$ & ee $\left.^{(\%)}\right)^{\mathrm{b}}$ \\
\hline 1 & 99 & 99 \\
\hline 2 & 99 & 99 \\
\hline 3 & 98 & 99 \\
\hline 4 & 99 & 99 \\
\hline 5 & 90 & 98 \\
\hline
\end{tabular}

a) All reactions were carried out in dry toluene $(1.5 \mathrm{~mL})$ under $1 \mathrm{~atm}$ hydrogen gas at $70{ }^{\circ} \mathrm{C}$ using $1 \mathrm{a}(0.6$ mmol), 3 (1.2 mmol), Novozyme-435 (15 mg), molecular sieves $4 \AA(300 \mathrm{mg})$ and pentadecane as internal standard. b) Determined using chiral GC and pentadecane as internal standard. Error in ee see Table 2.

In summary, we have developed a protocol for the DKR of primary benzylic amines using a recyclable catalyst consisting of palladium nanoparticles immobilized on siliceous aminofunctionalized mesocellular foam. It was found that the DKR proceeds well at both $70^{\circ} \mathrm{C}$ and $50^{\circ} \mathrm{C}$ and that a range of benzylic amines can be used as substrates. The DKR reactions with these relatively short reaction times were carried out with much lower catalytic loading than previously reported. To our delight, we could also demonstrate the first successful application of lipase PS in the DKR of amines. Future efforts will aim at incorporating other lipases and proteases in the present protocol. Also work will be dedicated to further improve the 
performance of the racemization part of the DKR reaction by developing related nanostructured catalysts.

\section{Experimental procedure}

\section{General}

${ }^{1} \mathrm{H}$ and ${ }^{13} \mathrm{C}$ NMR spectra were recorded at $400 \mathrm{MHz}$ and $100 \mathrm{MHz}$ respectively. GC analysis was made either on a system equipped with a CP-Chirasil-DEX CB column $(25 \mathrm{~m} \times 0.32 \mathrm{~mm}$ $\times 0.25 \mu \mathrm{m})$ with $\mathrm{H}_{2}$ as a carrier gas or IVADEX-I column $(25 \mathrm{~m} \times 0.25 \mathrm{~mm} \times 0.25 \mu \mathrm{m})$ with $\mathrm{N}_{2}$ as carrier gas. Both GCs had a gas flow of $1.8 \mathrm{~mL} / \mathrm{min}$ and were equipped with FID detectors. The high resolution mass spectra (HRMS) were recorded on an ESI-TOF mass spectrometer. 1-Phenylethylamine 1a was distilled and stored on molecular sieves before use. The remaining chemicals were purchased from commercial sources and used without further purification. Dry toluene was obtained from a VAC-solvent purifier. Flash chromatography was performed on an automated flash-machine equipped with an UV-detector using $12 \mathrm{~g}$ silica columns (particle size $40-63 \mu \mathrm{m}$ irregular, mesh size $230-400$, pore size $60 \AA$ ) with a solvent flow of $30 \mathrm{~mL} /$ minute. Reactions were monitored by thin-layer chromatography (TLC) using aluminum backed plates $(1.5 \AA \sim 5 \mathrm{~cm})$ pre-coated $(0.25 \mathrm{~mm})$ with silica gel and UV light as a visualizing agent. The Pd-AmP-MCF was synthesized according to previously described methods. ${ }^{10 \mathrm{~b}}$ CALB (Novozyme-435) and Lipase PS (Amano Lipase PS-C1) are available from commercial sources.

\section{General procedure for the dynamic kinetic resolution}

Method A: Pd-AmP-MCF (1.25 mol\%-5 mol\%, 10-40 mg), drying agent [Method A: molecular sieves $4 \AA$ (300 mg); Method B: dry $\left.\mathrm{Na}_{2} \mathrm{CO}_{3}(60 \mathrm{mg})\right]$ and Novozyme-435 (15 mg) were added to a vial equipped with a magnetic stirring bar and sealed with teflon cap. 
The vial was evacuated three times and refilled with hydrogen gas. Dry toluene $(1.5 \mathrm{~mL})$ was added to the vial and then the system was evacuated followed by refilling of hydrogen gas. The mixture was heated to the indicated temperature followed by addition of ethyl methoxyacetate $(141 \mu \mathrm{L}, 1.2 \mathrm{mmol})$ and amine substrate $(0.6 \mathrm{mmol})$ while stirred at $750 \mathrm{rpm}$. After reaching completion the reaction was diluted with ethyl acetate and washed with saturated sodium bicarbonate and brine. The organic phase was dried using $\mathrm{Na}_{2} \mathrm{SO}_{4}$, filtered and concentrated in vacuo. Purification was carried out using column chromatography.

Procedure for dynamic kinetic resolution with lipase PS. Pd-AmP-MCF (5 mol\%, $40 \mathrm{mg}$ ), dry $\mathrm{Na}_{2} \mathrm{CO}_{3}(60 \mathrm{mg})$ and Amano lipase PS-C1 $(200 \mathrm{mg})$ were added to a vial and sealed. The vial was evacuated three times and refilled with hydrogen gas. Dry toluene $(2.0 \mathrm{~mL})$ was added to the vial and the system was evacuated followed by refilling of hydrogen gas. The mixture was heated to $50{ }^{\circ} \mathrm{C}$ followed by addition of ethyl methoxyacetate $(141 \mu \mathrm{L}, 1.2$ mmol) and amine 1a $(0.6 \mathrm{mmol})$ while stirred at $750 \mathrm{rpm}$. Additional ethyl methoxyacetate $(70 \mu \mathrm{L}, 0.6 \mathrm{mmol})$ was added after 12 and $24 \mathrm{~h}$. After $36 \mathrm{~h}$ the reaction was diluted with ethyl acetate and washed with saturated sodium bicarbonate and brine. The organic phase was dried using $\mathrm{Na}_{2} \mathrm{SO}_{4}$, filtered and concentrated in vacuo. The crude product was purified by column chromatography $\left(\mathrm{SiO}_{2}\right.$, pentane/EtOAc 100:0 $\left.\rightarrow 0: 100\right)$ to give $95 \mathrm{mg}(82 \%)$ of a white solid in $99 \%$ ee.

Procedure for recycling of the Pd-MCF catalyst Pd-AmP-MCF (2.5 mol\%, $20 \mathrm{mg})$, molecular sieves $4 \AA$ (300 mg) and Novozyme-435 (15 mg) were added to a vial and sealed; the vial was evacuated three times and refilled with hydrogen gas. Dry toluene $(1.5 \mathrm{~mL})$ and internal standard pentadecane was added to the vial and then evacuated followed by refilling of hydrogen gas. The mixture was heated to $70{ }^{\circ} \mathrm{C}$ followed by addition of ethyl methoxyacetate $(141 \mu \mathrm{L}, 1.2 \mathrm{mmol})$ and 1-phenylethylamine $(0.6 \mathrm{mmol})$. After $15 \mathrm{~h}$ the reaction was analyzed using chiral GC and the catalyst was separated by using a pipette and 
washed in a separate tube using $4.5 \mathrm{~mL}$ of toluene and centrifuged (4100 rpm for $8 \mathrm{~min}$ ). Excess toluene was removed and the procedure was repeated again three times. The catalyst was dried under vacuum over night before use and the procedure was repeated.

(R)-2-Methoxy-N-(1-phenylethyl)acetamide (2a). The reaction was performed according to method A using $1.25 \mathrm{~mol} \%$ of Pd-AmP-MCF. The product was isolated after column chromatography $\left(\mathrm{SiO}_{2}\right.$, pentane/EtOAc 100:0 $\left.\rightarrow 0: 100\right)$ and afforded $115 \mathrm{mg}(99 \%)$ as a white solid in $99 \%$ ee. Experimental data were in accordance with those previously reported. ${ }^{13 b}{ }^{1} \mathrm{H}$ $\operatorname{NMR}\left(\mathrm{CDCl}_{3}, 400 \mathrm{MHz}\right): \delta=7.38-7.23(\mathrm{~m}, 5 \mathrm{H}), 6.75$ (br s, $\left.1 \mathrm{H}\right), 5.23-5.14(\mathrm{~m}, 1 \mathrm{H}), 3.95-$ $3.84(\mathrm{~m}, 2 \mathrm{H}), 3.40(\mathrm{~s}, 3 \mathrm{H}), 1.52(\mathrm{~d}, 3 \mathrm{H}, J=7.1 \mathrm{~Hz})$. Chiral GC separation: CP-Chirasil-DEX $\mathrm{CB}$ column $125^{\circ} \mathrm{C}-3{ }^{\circ} \mathrm{C} / \mathrm{min}-160^{\circ} \mathrm{C}, t_{\mathrm{R} 1}=11.9 \min (S), t_{\mathrm{R} 2}=12.3(R) \mathrm{min}$.

(R)-2-Methoxy-N-(1-m-tolylethyl)acetamide (2b). The reaction was performed according to method A using $1.25 \mathrm{~mol} \%$ of Pd-AmP-MCF. The product was isolated after column chromatography $\left(\mathrm{SiO}_{2}\right.$, pentane/EtOAc 100:0 $\left.\rightarrow 0: 100\right)$ and afforded $108 \mathrm{mg}(87 \%)$ as a white solid in 99\% ee. ${ }^{1} \mathrm{H}$ NMR $\left(\mathrm{CDCl}_{3}, 400 \mathrm{MHz}\right): \delta=7.26-7.21(\mathrm{~m}, 2 \mathrm{H}), 7.15-7.06(\mathrm{~m}, 2 \mathrm{H}), 6.73$ (br s, 1H), 5.20-5.10 (m, 1H), 3.95-3.84 (m, 2H), $3.40(\mathrm{~s}, 3 \mathrm{H}), 2.35(\mathrm{~s}, 3 \mathrm{H}), 1.50(\mathrm{~d}, 3 \mathrm{H}, J=$ $6.9 \mathrm{~Hz}) ;{ }^{13} \mathrm{C} \mathrm{NMR}\left(\mathrm{CDCl}_{3}, 100 \mathrm{MHz}\right): \delta=168.6,143.1,138.5,128.7,128.3,127.1,123.2$, 72.1, 59.2, 48.2, 22.1, 21.6. Chiral GC separation: IVADEX-I column $145{ }^{\circ} \mathrm{C}-2{ }^{\circ} \mathrm{C} / \mathrm{min}-200$ ${ }^{\circ} \mathrm{C}, \mathrm{t}_{\mathrm{R} 1}=13.7 \min (\mathrm{S}), \mathrm{t}_{\mathrm{R} 2}=14.1(\mathrm{R}) \min . \mathrm{HRMS}(\mathrm{ESI})$ : calc. for $[\mathrm{M}+\mathrm{Na}] \mathrm{C}_{12} \mathrm{H}_{17} \mathrm{NO}_{2} \mathrm{Na}$ : 230.1151, found $230.1143[\alpha]^{25}=+99.5\left(\mathrm{c} 0.2, \mathrm{CHCl}_{3}\right), 99 \%$ ee.

(R)-2-Methoxy-N-(1-phenylpropyl)acetamide (2c). The reaction was performed according to method A using $1.25 \mathrm{~mol} \%$ of Pd-AmP-MCF. The product was isolated after column chromatography $\left(\mathrm{SiO}_{2}\right.$, pentane/EtOAc 100:0 $\left.\rightarrow 0: 100\right)$ to give $120 \mathrm{mg}(97 \%)$ as a white solid in $97 \%$ ee. Experimental data were in accordance with those previously reported. ${ }^{13 \mathrm{~b}}{ }^{1} \mathrm{H}$ NMR $\left(\mathrm{CDCl}_{3}, 400 \mathrm{MHz}\right): \delta=7.37-7.24(\mathrm{~m}, 5 \mathrm{H}), 6.75($ br s, $1 \mathrm{H}), 4.96-4.89(\mathrm{~m}, 1 \mathrm{H}), 3.96-3.83(\mathrm{~m}$, 
2H), $3.41(\mathrm{~s}, 3 \mathrm{H}), 1.90-1.81(\mathrm{~m}, 2 \mathrm{H}), 0.90(\mathrm{t}, 3 \mathrm{H}, J=7.4 \mathrm{~Hz})$. Chiral GC separation: IVADEXI column $140{ }^{\circ} \mathrm{C}-1{ }^{\circ} \mathrm{C} / \min -200{ }^{\circ} \mathrm{C}, t_{\mathrm{R} 1}=12.8 \min (S), t_{\mathrm{R} 2}=13.0(R) \min$.

(R)-2-Methoxy-N-(1-p-tolylethyl)acetamide (2d). The reaction was performed according to method A using $1.25 \mathrm{~mol} \%$ of Pd-AmP-MCF. The product was isolated after column chromatography $\left(\mathrm{SiO}_{2}\right.$, pentane/EtOAc $\left.100: 0 \rightarrow 0: 100\right)$ in $113 \mathrm{mg}(91 \%)$ as a white solid in 98\% ee. Experimental data were in accordance with those previously reported. ${ }^{13 \mathrm{~b}}{ }^{1} \mathrm{H}$ NMR $\left(\mathrm{CDCl}_{3}, 400 \mathrm{MHz}\right): \delta=7.24-7.13(\mathrm{~m}, 4 \mathrm{H}), 6.71(\mathrm{br} \mathrm{s}, 1 \mathrm{H}), 5.20-5.10(\mathrm{~m}, 1 \mathrm{H}), 3.95-3.83(\mathrm{~m}$, 2H), $3.39(\mathrm{~s}, 3 \mathrm{H}), 2.33(\mathrm{~s}, 3 \mathrm{H}), 1.50(\mathrm{~d}, 3 \mathrm{H}, J=7.2 \mathrm{~Hz})$. Chiral GC separation: CP-ChirasilDEX CB column $125^{\circ} \mathrm{C}-3{ }^{\circ} \mathrm{C} / \min -160^{\circ} \mathrm{C}, t_{\mathrm{R} 1}=14.5 \min (\mathrm{S}), t_{\mathrm{R} 2}=14.8(\mathrm{R}) \min$.

(R)-2-Methoxy-N-(1,2,3,4-tetrahydronaphthalen-1-yl)acetamide (2e) The reaction was performed according to method A using $1.25 \mathrm{~mol} \%$ of Pd-AmP-MCF. The product was isolated after column chromatography $\left(\mathrm{SiO}_{2}\right.$, pentane/EtOAc 100:0 $\left.\rightarrow 0: 100\right)$ in $125 \mathrm{mg}(95 \%)$ as a white solid in $99 \%$ ee. Experimental data were in accordance with those previously reported. ${ }^{13 \mathrm{~b}}{ }^{1} \mathrm{H}$ NMR $\left(\mathrm{CDCl}_{3}, 400 \mathrm{MHz}\right): \delta=7.28-7.25,(\mathrm{~m}, 1 \mathrm{H}), 7.20-7.16(\mathrm{~m}, 2 \mathrm{H}), 7.13-$ $7.09(\mathrm{~m}, 1 \mathrm{H}), 6.75(\mathrm{br} \mathrm{s}, 1 \mathrm{H}), 5.28-5.20(\mathrm{~m}, 1 \mathrm{H}), 3.95(\mathrm{~s}, 2 \mathrm{H}), 3.39(\mathrm{~s}, 3 \mathrm{H}), 2.89-2.72(\mathrm{~m}$, 2H), 2.14-2.02 (m, 1H), 1.90-1.78 (m, 3H). Chiral GC separation: CP-Chirasil-DEX CB column $125{ }^{\circ} \mathrm{C}-20{ }^{\circ} \mathrm{C} / \min -150{ }^{\circ} \mathrm{C}-0.5{ }^{\circ} \mathrm{C} / \mathrm{min}-163{ }^{\circ} \mathrm{C}, t_{\mathrm{R} 1}=18.5 \mathrm{~min}(\mathrm{~S}), t_{\mathrm{R} 2}=18.9(\mathrm{R}) \mathrm{min}$.

(R)-2-Methoxy-N-(1-(4-methoxyphenyl)ethyl)acetamide (2f). The reaction was performed according to method $\mathrm{B}$ using $2.5 \mathrm{~mol} \%$ of $\mathrm{Pd}-\mathrm{AmP}-\mathrm{MCF}$. The product was isolated after column chromatography $\left(\mathrm{SiO}_{2}\right.$, pentane/EtOAc 100:0 $\left.\rightarrow 0: 100\right)$ in $129 \mathrm{mg}(96 \%)$ as a white solid in $99 \%$ ee. Experimental data were in accordance with those previously reported. ${ }^{13 b}{ }^{1} \mathrm{H}$ NMR $\left(\mathrm{CDCl}_{3}, 400 \mathrm{MHz}\right): \delta=7.29-7.22(\mathrm{~m}, 2 \mathrm{H}), 6.91-6.84(\mathrm{~m}, 2 \mathrm{H}), 6.69$ (br s, 1H), 5.19$5.09(\mathrm{~m}, 1 \mathrm{H}), 3.94-3.83(\mathrm{~m}, 2 \mathrm{H}), 3.79(\mathrm{~s}, 3 \mathrm{H}), 3.39(\mathrm{~s}, 3 \mathrm{H}) 1.50(\mathrm{~d}, 3 \mathrm{H}, J=6.8 \mathrm{~Hz})$. Chiral 
GC separation: IVADEX-I column $140{ }^{\circ} \mathrm{C}-1{ }^{\circ} \mathrm{C} / \min -200{ }^{\circ} \mathrm{C}, t_{\mathrm{R} 1}=21.8 \min (S), t_{\mathrm{R} 2}=22.3(R)$ $\min$.

(R)-2-Methoxy-N-(1-(4-(trifluoromethyl)phenyl)ethyl)acetamide (2g). The reaction was performed according to method B using $2.5 \mathrm{~mol} \%$ of Pd-AmP-MCF. The product was isolated after column chromatography $\left(\mathrm{SiO}_{2}\right.$, pentane/EtOAc 100:0 $\left.\rightarrow 0: 100\right)$ in $140 \mathrm{mg}(89 \%)$ as a white solid in $97 \%$ ee. Experimental data were in accordance with those previously reported. ${ }^{13 \mathrm{~b}}{ }^{1} \mathrm{H}$ NMR $(\mathrm{CDCl} 3,400 \mathrm{MHz}): \delta=7.59(\mathrm{~d}, 2 \mathrm{H}, J=8.3 \mathrm{~Hz}), 7.43(\mathrm{~d}, 2 \mathrm{H}, J=8.3$ Hz), 6.77 (br s, 1H), 5.24-5.17 (m, 1H), 3.95-3.85 (m, 2H), $3.42(\mathrm{~s}, 3 \mathrm{H}), 1.53(\mathrm{~d}, 3 \mathrm{H}, J=7.0$ Hz) Chiral GC separation: IVADEX-I column $145^{\circ} \mathrm{C}-2{ }^{\circ} \mathrm{C} / \min -200{ }^{\circ} \mathrm{C}, t_{\mathrm{R} 1}=10.6 \min (S), t_{\mathrm{R} 2}$ $=11.4(R) \min$.

\section{Acknowledgment}

Financial support from the Berzelius Center EXSELENT, the European Research Council (ERC AdG 247014), the Knut and Alice Wallenberg Foundation, and the Swedish Research Council are gratefully acknowledged. We thank Dr. Mozaffar Shakeri for carrying out preliminary experiments of this study.

\section{Supporting information}

Includes an investigation of the back ground chemical amidation, ${ }^{1} \mathrm{H}-\mathrm{NMR}$ of $\mathbf{2 a - 2 f}$ and ${ }^{13} \mathrm{C}$ NMR of $\mathbf{2 b}$ as well as GC chromatograms of compound 2a-2f. This material is available free of charge via the Internet at http://pubs.acs.org/. 


\section{References}

(1) Ding, K.; Uozumi, Y. Handbook of Asymmetric Heterogeneous Catalysis, Wiley-VCH: Weinheim, Germany, 2008.

(2) a) Polaina, J.; McCabe, A. P. Industrial enzymes structure, function and applications, Springer, Berlin, 2007 b) Houde, A.; Kademi, A.; LeBlanc, D. Appl. Biochem. Biotechnol. 2004, 118, 155 c) Faber K. Biotransformations in organic chemistry, 4th ed., Springer, Berlin, 2000.

(3) For recent reviews see: a) Kamal, A; Azhar, M. A.; Krishnaji, T.; Malik, M. S.; Azeeza, S. Coord. Chem. Rev. 2008, 252, 569; b) Marcos, R; Martín-Matute, B. M. Isr. J. Chem. 2012, 52,639 .

(4) a) Astruc, D.; Lu, F.; Aranzes, J. R. Angew. Chem. Int. Ed. 2005, 44, 7852; b) Somorjai, G. A.; Park. J. Y. Angew. Chem. Int. Ed. 2008, 47, 9212; c) An, K.; Somorjai, G. A. ChemCatChem 2012, 4, 1512; d) Chng, L. L.; Erathodiyil, N.; Ying, J. Y. Acc. Chem. Res. 2013, 46, 1825.

(5) a) Hulea, V.; Dumitriu, E. Nanomaterials in Catalysis, $1^{\text {st }}$ Ed (Eds. P. Serp. K. Phillopot). Wiley-VCH Weinheim, 2013, pp 375; b) Barakat, T.; Rooke, J. C.; Tidahy, H. L.; Hosseini, M.; Cousin, R.; Lamonier, J. -F.; Giraudon, J. -M.; De Weireld, G.; Su, B. -L.; Siffert, S. ChemSusChem 2011, 4, 1420.

(6) Jiang, H. -L.; Xu, Q. Chem. Commun. 2011, 47, 3351.

(7) Su, D. S. Nanomaterials in Catalysis, 1st Ed (Eds. P. Serp. K. Phillipot). Wiley-VCH: Weinheim, 2013, pp 331.

(8) a) Luque, R.; Balu, A. M.; Campelo, J. M.; Garcia, M. D.; Losada, E.; Pineda, A.; Romero, A. A.; Serrano-Ruiz, J. C. Catalysis 2012, 24, 253; b) Taguchi, A.; Schüth, F. Micropor. Mesopor. Mater. 2005, 77, 1.

(9) a) Schmidt-Winkel, P.; Lukens, Jr., W. W.; Yang, P.; Margolese, D. I.; Lettow, J. S.; Ying, J. Y.; Stucky, G. D. Chem. Mater. 2000, 12, 686; b) Taguchi, A.; Schüth, F. Micropor. Mesopor. Mater. 2005, 77, 1; c) Erathodiyil, N.; Ooi, S.; Seayad, A. M.; Han, Y.; Lee, S. S.; Ying, J. Y. Chem. Eur. J. 2008, 14, 3118; d) Shakeri, M.; Engström, K.; Sandström, A.; Bäckvall, J. -E. ChemCatChem 2010, 2, 534; e) Ping, E. W.; Wallace, R.; Pierson, J.; Fuller, T. F.; Jones, C. W. Micropor. Mesopor. Mater. 2010, 132, 174; f) Ping, E. W.; Pierson, J.; Wallace, R.; Miller, J. T.; Fuller, T. F.; Jones, C. W. Appl. Catal. A 2011, 396, 85; g) Na- 
Chiangmai, C.; Tiengchan, N.; Kittisakmontree, P.; Mekasuwandurong, O.; Powell, J.; Panpronot, Catal. Lett. 2011, 141, 1149.

(10) a) Shakeri, M.; Tai, C. -W.; Göthelid, E.; Oscarsson, S.; Bäckvall, J. -E.; Chem. Eur. J. 2011, 17, 13269; b) Johnston, E. V.; Verho, O.; Kärkäs, M. D.; Shakeri, M.; Tai, C. -W.; Palmgren, P.; Eriksson, K.; Oscarsson, S.; Bäckvall, J. -E. Chem. Eur. J. 2012, 18, 12202; c) Engström, K.; Johnston, E. V.; Verho, O.; Gustafson, K. P. J.; Shakeri, M.; Tai, C. -W.; Bäckvall, J. -E. Angew. Chem. Int. Ed. 2013, 52, 14006; d) Verho, O.; Nagendiran, A.; Johnston, E. V.; Tai, C. -W.; Bäckvall, J. -E. ChemCatChem 2013, 5, 612; e) Verho, O.; Nagendiran, A.; Tai, C. -W.; Johnston, E. V.; Bäckvall, J. -E. ChemCatChem 2014, 6, 205; f) Deiana, L.; Jiang, Y.; Palo-Nieto, C.; Verho, O.; Johnston, E. V.; Córdova, A. Angew. Chem. Int. Ed. 2014, 53, 3447.

(11) Kim, Y.; Park, J.; Kim, M.-J. Chem. Cat. Chem. 2011, 3, 271.

(12) Example using CALB as biocatalyst: a) Thalén, L. K.; Zhao, D.; Sortais, J.-B.; Paetzold, J.; Hoben, C.; Bäckvall, J.-E. Chem. Eur. J. 2009, 15, 3403; Example using CALA as biocatalyst. b) Engström, K.; Shakeri, M.; Bäckvall, J.-E. Eur. J. Org. Chem. 2011, 10,1827; Example using Candida Rugosa as biocatalyst: c) Stirling, M.; Blacker, J.; Page, M. I. Tetrahedron Lett. 2007, 48, 1247.

(13) a) Paetzold, J.; Bäckvall, J.-E. J. Am. Chem. Soc. 2005, 127, 17620; b) Kim, M.-J.; Kim, W.-H.; Han, K; Kyung Choi, Y; Park, J. Org. Lett. 2007, 9, 1157; c) Kim. Y.; Park, J.; Kim, M.-J. Tetrahedron Lett. 2010, 51, 5581; d) Parvulescu, A. N.; Jacobs, D.E.; De Vos, D. E. Chem. Eur. J. 2007, 13, 2034; e) Parvulescu, A. N.; Jacobs, D.E.; De Vos, D. E. Appl. Catal. A 2009, 255, 206. f) Han, K.; Kim, Y.; Park, J; Kim, M.-J. Tetrahedron Lett., 2010, 51, 3536; g) Geukens, I.; Plessers, E.; Jin Won, S.; De Vos, D. E. Eur. J. Inorg. Chem. 2013, 14, 2623; h) Qianru, J.; Guoqing, J.; Yanmei, Z. Can, L. Catal. Sci. Technol. 2014, 4, 464.

${ }^{14}$ F. Balkenhohl, K. Ditrich, B. Hauer, W. Ladner, J.Prakt. Chem. 1997, 339, 381

${ }^{15}$ See Supporting information.

${ }^{16}$ Running the same reaction at $70{ }^{\circ} \mathrm{C}$ for $36 \mathrm{~h}$ gave $2 \mathrm{a}$ with only $92 \%$ ee.

(17) Varma, R.; Kasture, S. M.; Gaikwad, B. G.; Nene, S.; Kalkote, U. R. Asian journal of Biochemistry 2007, 2, 279-283.

${ }^{18}$ Elemental analysis of the reaction mixture for the first three cycles revealed that the leaching of palladium in the first two cycles was negligible $(<0.2 \mathrm{ppm})$ and in the third cycle it was to $1.8 \mathrm{ppm}$. The latter number is still very low and corresponds to only $0.15 \%$ of the total palladium amount used in the reaction. 


\section{TOC}

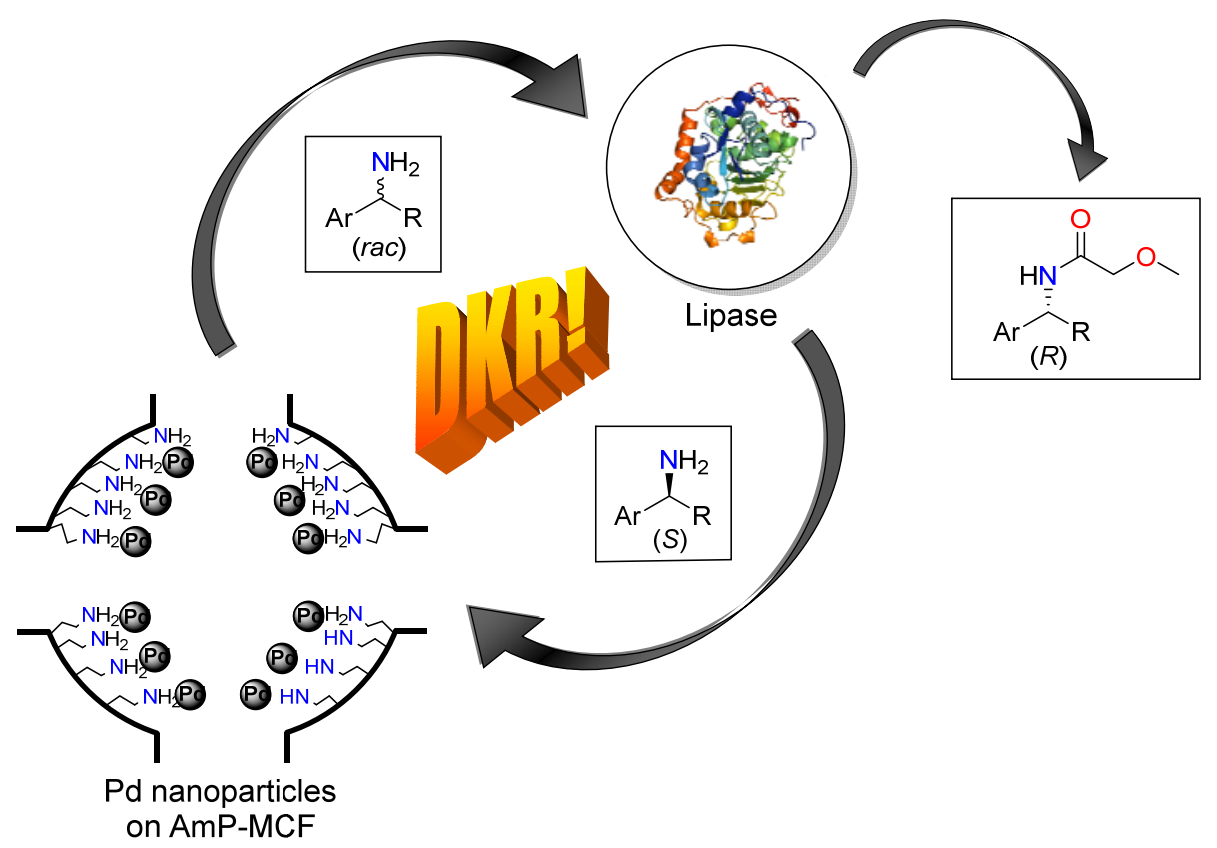

